\title{
From Separate Legal Entity to Economic Unity: The Criminal Liability of Parent Company
}

\author{
Mahrus Ali \\ Universitas Islam Indonesia. E-mail: mahrus_ali@uii.ac.id
}

\section{ARTICLE INFO}

\section{Keywords:}

criminal liability; parent's company; separate legal entity; subsidiary's offense

How to cite:

Ali, M.(2019). From Separate Legal Entity to

Economic Unity: The

Criminal Liability of

Parent Company. MEDIA

HUKUM, +62274

387656 (Ext. 220)

Article History:

Received: 03-09-2019

Reviewed: 15-10-2019

Revised: 21-12-2019

Accepted: 23-12-2019

\begin{abstract}
Corporate criminal liability has become an issue following the increase in corporate crimes. This study discusses the possibility of parent company to deny liability for crimes committed by its subsidiary companies. This normative legal research employed qualitative analysis. The results showed that the parent company denied criminal liability by hiding behind the separate legal entities and limited liability doctrine. Through both doctrines, the parent company treats itself as a separate legal entity apart from the subsidiary company so that the former holds no liability for any crime committed by latter. Through piercing the corporate veil doctrine, the parent company intentionally uses the subsidiary company as a tool to maximize profits and applies total control. Therefore, based on the vicarious liability principle, the subsidiary company functioned as the parent company's agent. It works for or on behalf of the parent company in which every profit made is owned by the parent company.
\end{abstract}

DOI: 10.18196/jmh.20190131

Copyright (c) 2019 MEDIA HUKUM. All rights reserved.

\section{Introduction}

It is common argues that a subsidiary company violates a criminal law with a more significant loss than that of an individual or corporation. It is considered challenging to hold the parent company's criminal liability for the offense since both parent company and subsidiary are separate and independent legal entity according to different perspective of legal entity doctrine. ${ }^{1}$ The parent company holds limited liability in terms of the stock invested in the subsidiary. Consequently, criminal acts committed by the subsidiary cannot be imposed on the parent company in terms of its criminal liability.

Corporate criminal liability has not reached the existence of parent company, which consists of one parent company and several subsidiaries with various business activities spread across developing countries. The doctrine in criminal law states that

1 Vivian, G.C. (2017). "Harmonizing Multinational Parent Company Liability for Foreign Subsidiary Human Rights Violation". Chicago Journal of International Law, 17: 408. 
corporate crime must not be committed directly by the corporation but by other parties for and/or on behalf of the corporation. ${ }^{2}$ It means that corporate crime will always be a functional action. ${ }^{3}$. Based on the doctrine of a separate legal entity, the officials, in this case those who hold independent law positions. The officials are in charge of managing the subsidiary - not the parent company's officials.

The parties that are criminally responsible embrace those involved in subsidiaries such as corporations and corporate directors. The parent company irrevocably holds no criminal liability for the offense committed by its subsidiary, which has a legal entity in Indonesia. Dropping off parent company from being criminally responsible for the crime committed by its subsidiary is an injustice - especially when society becomes the victim. It is, therefore, urgent to analyze the use of separate legal entities and limited liability by the parent company as the basis for escaping legal responsibility for the offense committed by its subsidiary and the reason why parent company has to accept the liability. Further, it also analyzes the criminal liability of parent companies for the subsidiary's offense.

\section{Method}

Law in this study is perceived as a set of doctrines, legal norms, and a court decision. Thus, this study belongs to normative legal research. The legal aspects of this research are dealing with theory, doctrine, legal norms, and court decisions that allow the parent company to be criminally liable for the offense committed by its subsidiary. This study is analyzed qualitatively in the form of description and criticism of the relationship between legal theory and doctrine with economic reality, and description of piercing the corporate veil and vicarious liability as the theoretical basis of the corporation's liability for the offense committed by its subsidiary.

\section{Analysis and Results}

\subsection{The Use of Separate Legal Entity and Limited Liability Doctrine by Parent Company}

The separate legal entity is a prevailing doctrine applied to the subsidiary. The theory states that corporations and shareholders are two independent legal entities separate from one another. According to Philip I. Blumberg, ${ }^{4}$ corporation as a separate legal entity is recognized by law to which some fundamental attributes are attached, and they involve: holding the capacity to prosecute and be prosecuted, owning and transferring property, having ongoing existence, which is separate from individuals or other parties, and owning shares over the time and from the shareholders' rights to transfer their shares without any effect on the existence of the corporations.

The doctrine implies the legal responsibilities of two different legal entities. When shareholders and corporations become two separate legal entities, two consequences

2 Waller, L \& Williams, C.R. (2005). Criminal Law Text and Cases. Australia: Butterworhts

3 Jan, R. (2003). Hukum Pidana Komentar atas Pasal-pasal Terpenting dari Kitab Undang-undang Hukum Pidana Belanda dan Padanannya dalam Kitab Undang-undang Hukum Pidana Indonesia, translated by Tristam Pascal Moeliono, Jakarta: PT. Gramedia Pustaka Utama.

4 Blumberg, P.I. (1990). “The Corporate Entity in an Era of Multinational Corporations”. Delaware Journal of Corporate Law, 15: 286. 
exist. Shareholders or other parties are only liable for the limited capital invested in the corporation. ${ }^{5}$ Unless the shareholders, directors, or corporate employees hold liability on behalf of a corporation's independent legal entity, they cannot hold responsibility for the corporation's debts and obligations. ${ }^{6}$ The shareholders, thus, have to be protected from the corporation's debts (owner shielding). Also, the corporation cannot hold the liability or be protected from the debts or the shareholders' losses (entity shielding). ${ }^{7}$

The limitation of corporate liability is known as limited liability. The founders and shareholders of the company are solely liable for the paid-up capital. The shareholders are not personally responsible for the engagement made on behalf of the company and the company's loss exceeding its shares. The shareholders, in fact, are only responsible for the company's paid-up capital - not exceed paid-up capital, and they cannot hold liability for what the company has done. ${ }^{8}$ According to Karin Schwindt, ${ }^{9}$ The underlying reason of limited liability is that the partners and shareholders are allowed to invest in the corporation without any risks treating their assets.

Both doctrines are then used to measure the parent company's position as a legal entity separate from its subsidiary company. The parent company cannot hold liability for the actions taken by the subsidiary company. The doctrine is used as a weapon for the parent company to get rid of criminal liability for the offense committed by its subsidiary company ${ }^{10}$, as in two cases. In Bhopal case occurred in India, even though the prosecutor stated that as a multinational integrated company, Union Carbide as the parent company should have held liability for the offense committed by its subsidiary, Bhopal. The US court rejected the reason by referring to the doctrine of separate legal entity and limited liability. ${ }^{11}$. In a lawsuit against Freeport-McMoran, Inc. base in Louisiana, Beanal, as the representative of the Amungme tribe, denied that P.T. Freeport Indonesia has polluted and damaged the environment, violated human rights, and committed genocide by devastating the surrounding ecosystem - changing rivers into toxic waste disposal, dumping toxic waste to the river banks, committing torture, conduction extrajudicial killing, and doing arbitrary arrests. By such a lawsuit, Louisiana district court rejected the argument based on the fact that PT committed the crimes. Freeport Indonesia, as the subsidiary of Freeport-McMoran, Inc. Therefore, criminal liability charged to the subsidiary. ${ }^{12}$

5 Christopher, W.P. (2017). "Piercing the Corporate Veil by Tort Creditors". Journal of Business $\mathcal{E}$ Technology Law, 13: 67-68. K. Vandervoort, Jeffrey. (2004). "Piercing the Veil of Limited Liability Companies: The Need for a Better Standard". DePaul Business \& Commercial Law Journal, 4: 51-53.

6 Elizabeth, S.M. (2009). “Are There Limits on Limited Liability? Owner Liability Protection and Piercing the Veil of Texas Business Entities". Texas Journal of Business Law, 43: 405-406.

7 Hespe, K. (2013). "Preserving Entity Shielding: How Corporations Should Respond to Reverse Piercing of the Corporate Veil". Journal of Business \& Securities Law, 14: 69-71.

8 Ibid

9 Karin, S. (1997). “Limited Liability Companies: Issues in Member Liability”. UCLA Law Review, 44: 1541-1549.

10 Dorward, D.J. (1998). "The Forum Non Conveniens Doctrine and the Judicial Protection of Multinational Corporations from Forum Shopping Plaintiffs". University of Pennsylvania Journal of International Economic Law, 19: 141-145.

11 Peter M. (2010). "Limited Liability and Multinational Enterprises: A Case for Reform?". Cambridge Journal of Economics, 921

12 Zia-Zarifi, S. (1999). "Suing Multinational Corporations in the U.S. for Violating International Law". UCLA Journal of International Law and Foreign Affairs, 4: 98-99. 
The parent company exploits the doctrine to escape criminal liability for any violations of criminal law committed by its subsidiary. If the parent company strategically limits the occurrence of harmful actions within a separate entity, corporate fiction ensures that each parent and subsidiary are legally independent of each other even though both have economic dependence. Therefore, limited liability doctrine protects the parent company to escape legal liability. ${ }^{13}$ Why does parent company use both doctrines to avoid criminal liability? Beth Stephens asserts: ${ }^{14}$

\begin{abstract}
Large corporations magnify the consequences of the amoral profit motive. Multiple layers of control and ownership insulate individuals from a sense of responsibility for corporate actions. The enormous power of multinational corporations enables them to inflict greater harm, while their economic and political clout renders them difficult to regulate.
\end{abstract}

Economic and political factors are the ones making parent company escape criminal liability. By its enormous political and economic power, the parent company is likely to bring higher losses while its economic and political power makes it difficult to hold criminal liability. Consequently, the parent company wants to avoid financial losses as there will be many financial losses if the parent company retains responsibility for the offense committed by its subsidiary. It is because the crime committed by a subsidiary is not only related to social and economic losses, but also ecological aspects.

\title{
3.2. From Separate Legal Entity Doctrine to Economic Unity
}

The separate legal entity and limited liability doctrines denied by parent company purpose to get rid of the parent company's criminal liability for the offense committed by a subsidiary company. If the separate legal entity doctrine states that each unit of the parent company is treated as a separate legal entity, then the limited liability transfers the risks exceeding the parent company's investment to the subsidiary. The strict separation of the parent company and its subsidiary, after all, is an artificial legal construct that generates an imbalance of economic reality and fails to meet the multilevel conditions of the parent company in the modern world. ${ }^{15}$

The parent company-subsidiary relationship, on the one hand, is frequently more intensive than separate legal entity doctrine itself. Through the increase and diversification of the parent company in the last decade, the awareness that the parent company does not need to be understood as a separate legal entity seems to grow. Conglomerate consists of complex corporate networks, with the control over the subsidiary in a parent company's liability. On the other hand, legal transposition concerning the concept of the separate legal entity attached to corporate is mainly mechanical concept. The concept historically aims at protecting investors from liability for corporate debt. ${ }^{16}$.

13 Kirshner, J.A. (2012). "Why Is the U.S. Abdicating the Policing of Multinational Corporations to Europe?: Extraterritoriality, Sovereignty, and the Alien Tort Statute". Berkeley Journal of International Law, 264.

14 Beth, S. (2002). "The Amorality of Profit: Transnational Corporations and Human Rights". Berkeley Journal of International Law, 20 (45): 46.

15 Stoitchkova, D.E. (2010). Towards Corporate Liability in International Criminal Law. Dissertation, Utrecht University: School of Human Rights Research Series. p.140.

16 Ibid, p.141. 
Although limited liability doctrine leads to the consequence of the separation of corporate legal entities from shareholders or other involved parties, it is frequently used to protect the parent company from escaping the legal liability for the offense committed by its subsidiary, the isolation of such liability is not absolute. The economic unity between parent and subsidiary company becomes the reason why the parent company needs to hold accountability for the offense committed by its subsidiary. ${ }^{17}$. The economic profit generated by a subsidiary is owned by the parent company even though both of them are separate legal entities.

The doctrine of separate legal entity between a parent company and its subsidiaries views only from a law perspective. The law cannot be separated from non-legal power like the economy. Therefore, economic factors play a critical role in forming and enforcing the law. The transition from separate legal entity doctrine to economic unity doctrine in the accounting parent company for the offense committed by its subsidiary is an attempt to rationalize the economic rationality of the parent company. ${ }^{18}$ The parent company is based not only on motivation (obeying the law) law but also on a financial calculation by maximizing the expected utility. ${ }^{19}$

\subsection{Parent Company's Criminal Liability for Subsidiary's Offense}

To make parent company criminally liable for the offense committed by the subsidiary, it is relevant to use piercing the corporate veil doctrine. This doctrine is to ensure longlasting justice, to avoid doctrine justification of any mistake, and unprotected frauds. ${ }^{20}$ The parent company that does not hold any liability begins to comply with laws. ${ }^{21}$ Piercing the corporate veil is the opposite of limited liability doctrine. In Act Number 40, 2007 on the limited company, the doctrine is written in article 3, verse (2) stating that:

Limited liability of a shareholder is not applicable if:

a. The company does not meet/has not met the requirement as a legal entity;

b. The shareholders that are both, directly and indirectly, involved exploit the company for personal concerns;

c. The shareholders have involved an offense committed by the company; or

d. The shareholders that are both, directly and indirectly involved violating the law by using the company's wealth, making the company unable to pay off the debt.

The parent company that holds liability for the subsidiary's mistakes and the offense can be carried out by judging the time when a separate legal entity and limited liability doctrines have no longer theoretical and factual justifications, so the doctrine of

\footnotetext{
17 Kirshner, J.A. Op.cit. 264.

18 E. Cognetti, C.E. (2016). “A Single Call. The Need to Amend the Parent-Subsidiary Relationship under the FTAIA in View of Motorola Mobility". Fordham Journal of Corporate and Financial Law, 21: 639-640.

19 Laín, P.A. (2018). “On the Scope of Economic Efficiency in Judicial Reasoning. A Pattern Derived from U.S. Case Law on Corporations". Lincoln Law Review, 45: 56.

${ }^{20}$ Klein, S.M. (1996). "Piercing the Veil of the Limited Liability Company, from Sure Bet to Long Shot: Gallinger V. North Star Hospital Mutual Assurance, Ltd". Journal of Corporation Law, 22: 136.

21 Oh, P.B. (2013). “Veil-Piercing Unbound”. Boston University Law Review, 93: 90.
} 
piercing the corporate veil is considered relevant to be used. Elizabeth S. Miller states that the ignorance of the existence of the parent company as a separate legal entity from its subsidiary when such separation causes injustice, ${ }^{22}$ Whereas there are factually several possibilities related to this condition. The subsidiary is only used as a tool by the parent company to generate maximum profits and total control. ${ }^{23}$ To hold the parent company responsible for the offense committed by its subsidiary based on the theory of alter ego, it needs to prove that the shareholders or parent company dominates all subsidiary's business activities, although both are separate legal entities. ${ }^{24}$ The parent company interferes in it is the subsidiary's business activities or controls all policies and business activities of its subsidiaries. ${ }^{25}$ The parent company, therefore, has to be criminally liable for all losses, frauds, and offense committed by its subsidiary.

Once the parent company's cloak is unveiled, the subsidiary, in fact, only stands as the parent company's agent. In this context, vicarious liability theory derived from respondeat superior is a theoretical base for the parent company to hold criminal liability. Vicarious liability, also known as a joint responsibility, is a legal theory of liability that empowers the court to keep a person liable for the acts of others. According to this doctrine, a corporation can only take action through the agent, give authority to the agent, and take profits from the agent's actions, so it cannot be separated from the agent's activity. ${ }^{26}$

Vicarious liability is one of those liabilities that is imposed on one person for the wrongful actions of another person. Individuals can be made vicariously liable for a criminal act of others even if they merely helped to further the crime in some way example, aiding and abetting illegal activities. It often occurs in the context of civil law. In a criminal context, vicarious liability assigns guilt, or criminal liability, to a person for wrongful acts committed by someone else. This doctrine is considered to be fundamentally flawed under criminal law because it is based on respondent superior principles that are concerned with distributing loss caused by the tortious act. It is only the agents who act for/on behalf of the corporation and are able to commit a criminal offense and make mistakes. The corporation holds criminal liability for the criminal offense committed by the agents if the crime is undertaken on behalf of the corporation or in order to generate profits for the corporation, or determined to be within the scope of employment. ${ }^{27}$

22 Elizabeth, S. M, op.cit, 405-407.

23 Christopher, W.P. (2018). "Piercing the Corporate Veil in Nebraska". Creighton Law Review, 51: 250-251.

24 Leverberg, P.N. (2019). "The Mystery of the Corporate Veil: Comparing Anglo-American Jurisdictions". Penn State Journal of Law \& International Affairs, 7: 121-123.

25 Tracy, E. (2017). “Imputed Liability: How to Determine When Parent Companies Should be Held Liable for the Patent Infringements of Their Subsidiary Companies". Missouri Law Review, 82: 573-574.

26 Jeffrey,R.E. (2004). "Holding Corporate Officers Criminally Responsible for Environmental Crimes: Collapsing the Doctrines of Piercing the Corporate Veil and the Responsible Corporate Officer". New England Journal on Criminal and Civil Confinement, 30:314.

27 Jeffrey,R.E. (2004). “Holding Corporate Officers Criminally Responsible for Environmental Crimes: Collapsing the Doctrines of Piercing the Corporate Veil and the Responsible Corporate Officer". New England Journal on Criminal and Civil Confinement, 30: 314. 
A corporation holds criminal liability for the offense committed by its administrators or employees working within their scope. ${ }^{28}$ Their scope of employment is determined partially by their past activities, and it can be expanded to their failure in taking the actions. ${ }^{29}$ Three requirements need to be met by a corporation to hold liability for the offense committed by its agents, and they consist of the fact that the agent commits a crime/offense, it occurs within the scope of employment or with the intent to benefit the corporation. ${ }^{30}$ These requirements are met if they are related to the corporation's liability for the offense committed by the subsidiary. The subsidiary is a parent company's agent. Although both of them stand as independent and separate entities, the fact shows that subsidiaries in developing countries only function as legal-based agents in most of the developed countries. The criminal offense committed by a subsidiary occurs in the scope of employment. As a subsidiary, in which the power, management, and company's working culture, human resources, and financial support merge with the parent company, all of the business actions are said to be the subsidiary's criminal offense committed in its scope of employment as the parent company's agent. Lastly, business profits generated by the subsidiary are, by all means, owned by the parent company. The profits made from such actions as tax evasion must belong to the parent company.

In Indonesia, the application of vicarious liability theory on group companies which have similar characteristics to the parent company was found in the court decision of Asian Agri Group (AAG). In this decision, the one proposed as the defendant was Suwir Laut, also known as Che Sui Atak, who was an employee of P.T Indosawit Subur as one of the AAG's subsidiaries - he was functionally in charge of being AAG's Tax Manager based in Jakarta. The defendant was proved to deliberately submit notification letter, and/or invalid and incomplete information on behalf of PT. Dasa Anugerah Sejati, PT. Sadudara Sejati Luhur, PT. Indo Sepadan Jaya, PT. Nusa Pusaka Kencana, PT. Andalas Intiagro Lestari, PT. Igunas Agre Utama, PT. Rantau Sinar Karsa, PT. Supora Matra Abadi, PT. Mitra Unggul Perkasa, PT. Hari Sawit Jaya, PT. Inti Idosawit Subur, and PT. Gungang Melayu which were all incorporated within (AAG) so that it caused national losses of IDR.1.259.977.695,652.

In this case, AAG was punished by a fine of two times from the state loss, which is IDR. 2,519,955,391,304. The exciting part of this decision was that 'although the defendant was the employee of PT. Indosawit Subur, a subsidiary of AAG, as the criminal offense was committed on behalf of 14 subsidiaries incorporated in the AAG, it is not only the defendant who was criminally charged but also AAG as the parent company for the reason to realize legal justice'. From the judge's judicial considerations, it is stated that 'the act of the defendant was based on the business concerns of 14 corporations in which the defendant represented to avoid income tax and corporation tax that was supposed to be paid, it was considered unfair for the defendant, as an individual, to hold criminal liability, so the corporation needed to hold the liability, as well, which benefited from the tax evasion'. ${ }^{31}$

\footnotetext{
28 John, L.W. (2017). "A Confused Sea: Vicarious Liability for Punitive Demages under Maritime Law". Tulane Law Review, 91: 714-715.

29 Pitt, H.L \& Groskaufmanis, K.A. (1990). “Minimizing Corporate Civil and Criminal Liability: A Second Look at Corporate Codes of Conduct". Georgetown Law Journal, 78: 1571.

30 Michael, S.M. (2018). “The Strictness of Strict Liability”. Criminal Law and Philosophy, 12: 522-523.

31 Supreme Court Decision Number 2239 K/Pid.Sus/2012
} 
It was also mentioned in another legal consideration that although individually the act of the defendant occurred due to 'mens rea' of the defendant, since the action was solely for the corporation's concerns, the Supreme Court argued that what the defendant did was wanted or 'mens rea' of the 14 corporations so that imposition of individual liability with corporate liability needed to be simultaneously implemented as a reflection of respondeat superior doctrine, or vicarious liability doctrine was applied to the corporation on the act of the defendant's act as corporation's personifications in which he represented. More importantly, what the defendant did was decided collectively. 32

The considerations show that in holding liability for the tax evasion committed by 14 subsidiaries, the judging panel referred to characteristics of the vicarious liability theory. There was a working relationship between the defendant and the AAG. The defendant worked as an employee at PT. Indosawit Subur, one of the companies under AAG, functionally served as AAG's Tax Manager, based in Jakarta. The offense committed by the defendant was not on behalf of himself that of AAG in the form of tax evasion committed by fourteen AAG subsidiaries from 2002 to 2005 . The profits generated from tax evasion did not belong to the defendant but by AAG.

\section{Conclusion}

Both separate legal entities and limited liability doctrine were initially intended to improve the investment climate and professionalism of the shareholder and corporation. But along with its development, both are employed by a parent company to escape legal liability for the criminal offense committed by its subsidiary. That's why they need the parent company's criminal liability for the crime committed by its subsidiary based on economic unity between the parent company and its subsidiary. Although they are independent and separate legal entities, the fact showed that the profits made by the subsidiary belong to the parent company.

Through the doctrine of piercing the corporate veil, the parent company must be liable for the offense committed by its subsidiary. The parent company is proved to only use its subsidiary as a tool to generate maximum profits and grow total power. Shareholder and parent companies dominate all of the subsidiary's business activities, although they stand as separate legal entities. Based on the vicarious liability theory, the subsidiary is a parent company's agent. The criminal offense committed by a subsidiary occurs in the scope of employment. All of the business actions are said to be the subsidiary's criminal offense committed in its range of employment as the parent company's agent. Business profits generated by a subsidiary are, by all means, owned by the parent company. The theory was used to make Asian Agri Group criminally liable for the offense committed by its 14 subsidiaries.

\section{References}

Books:

Remmelink, J. (2003). Hukum Pidana Komentar atas Pasal-pasal Terpenting dari Kitab Undang-undang Hukum Pidana Belanda dan Padanannya dalam Kitab Undang-

32 Ibid 
undang Hukum Pidana Indonesia, translated by Tristam Pascal Moeliono, Jakarta: PT. Gramedia Pustaka Utama

Waller, L \& Williams, C.R. (2005). Criminal Law Text and Cases. Australia: Butterworhts

\section{Journal Articles:}

Beth, S. (2002). "The Amorality of Profit: Transnational Corporations and Human Rights". Berkeley Journal of International Law, 20.

Blumberg, P.I. (1990). “The Corporate Entity in an Era of Multinational Corporations". Delaware Journal of Corporate Law, 15.

Christopher, W.P. (2017). "Piercing the Corporate Veil by Tort Creditors". Journal of Business \& Technology Law, 13: 67-68.

Christopher, W.P. (2018). "Piercing the Corporate Veil in Nebraska". Creighton Law Review, 51.

Cognetti, C.E. (2016). "A Single Call. The Need to Amend the Parent-Subsidiary Relationship under the FTAIA in View of Motorola Mobility". Fordham Journal of Corporate and Financial Law, 21.

Dorward, D.J. (1998). “The Forum Non Convenien Doctrine and the Judicial Protection of Multinational Corporations from Forum Shopping Plaintiffs". University of Pennsylvania Journal of International Economic Law, 19.

Elizabeth, S.M. (2009). "Are There Limits on Limited Liability? Owner Liability Protection and Piercing the Veil of Texas Business Entities". Texas Journal of Business Law, 43.

Hespe, K. (2013). "Preserving Entity Shielding: How Corporations Should Respond to Reverse Piercing of the Corporate Veil". Journal of Business $\mathcal{E}$ Securities Law, 14

Jeffrey, K.V. (2004). "Piercing the Veil of Limited Liability Companies: The Need for a Better Standard". DePaul Business \& Commercial Law Journal, 4.

Jeffrey, R.E. (2004). "Holding Corporate Officers Criminally Responsible for Environmental Crimes: Collapsing the Doctrines of Piercing the Corporate Veil and the Responsible Corporate Officer". New England Journal on Criminal and Civil Confinement, 30.

John, L.W. (2017). “A Confused Sea: Vicarious Liability for Punitive Demages under Maritime Law". Tulane Law Review, 91.

Karin, S. (1997)." Limited Liability Companies: Issues in Member Liability". UCLA Law Review, 44.

Kirshner, J.A. (2012). "Why Is the U.S. Abdicating the Policing of Multinational Corporations to Europe?: Extraterritoriality, Sovereignty, and the Alien Tort Statute". Berkeley Journal of International Law.

Klein, S.M. (1996). "Piercing the Veil of the Limited Liability Company, from Sure Bet to Long Shot: Gallinger V. North Star Hospital Mutual Assurance, Ltd". Journal of Corporation Law, 22. 
Laín, P.A. (2018). “On the Scope of Economic Efficiency in Judicial Reasoning. A Pattern Derived from U.S. Case Law on Corporations". Lincoln Law Review, 45.

Leverberg, P.N. (2019). "The Mystery of the Corporate Veil: Comparing AngloAmerican Jurisdictions". Penn State Journal of Law \& International Affairs, 7.

Michael, S.M. (2018). “The Strictness of Strict Liability". Criminal Law and Philosophy, 12.

Oh, P.B. (2013). “Veil-Piercing Unbound". Boston University Law Review, 93 (1), 89-137, ISSN 0006-8047.

Peter, M. (2010). “Limited Liability and Multinational Enterprises: A Case for Reform?" Cambridge Journal of Economics.

Pitt, H.L \& Groskaufmanis, K.A. (1990). “Minimizing Corporate Civil and Criminal Liability: A Second Look at Corporate Codes of Conduct". Georgetown Law Journal, 78.

Tracy, E. (2017). “Imputed Liability: How to Determine When Parent Companies Should be Held Liable for the Patent Infringements of Their Subsidiary Companies". Missouri Law Review, 82.

Vivian, G.C. (2017). “Harmonizing Multinational Parent Company Liability for Foreign Subsidiary Human Rights Violation". Chicago Journal of International Law, 17.

Zia-Zarifi, S. (1999). "Suing Multinational Corporations in the U.S. for Violating International Law". UCLA Journal of International Law and Foreign Affairs, 4.

\section{Research Report, Thesis, Dissertation:}

Stoitchkova, D.E. (2010). “Towards Corporate Liability in International Criminal Law". (Dissertation)". Utrecht University: School of Human Rights Research Series.

\section{Court Decision:}

Supreme Court Decision Number 2239 K/Pid.Sus/2012 